\title{
Impact of European Funds on Value Creation of Portuguese Companies
}

\author{
Nuno Teixeira ${ }^{1,}$, Luís Vitorino ${ }^{1}$, Rui Brites ${ }^{2}$, Teresa Godinho ${ }^{1}$ \\ ${ }^{1}$ Department of Accounting and Finance, Business School of Polytechnic Institute of Setúbal, Setúbal, Portugal \\ ${ }^{2}$ Department of Management, Business School of Polytechnic Institute of Setúbal, Setúbal, Portugal \\ Email address: \\ nuno.teixeira@esce.ips.pt (N. Teixeira),lv21@live.com.pt (L. Vitorino), rui.brites@esce.ips.pt (R. Brites), \\ teresa.godinho@esce.ips.pt (T. Godinho) \\ ${ }^{*}$ Corresponding author
}

\section{To cite this article:}

Nuno Teixeira, Luís Vitorino, Rui Brites, Teresa Godinho. Impact of European Funds on Value Creation of Portuguese Companies. International Journal of Accounting, Finance and Risk Management. Special Issue: Perspectives on Risk Management and Impact on Sustainability of Companies. Vol. 5, No. 1, 2020, pp. 1-11. doi: 10.11648/j.ijafrm.20200501.11

Received: December 24, 2019; Accepted: December 31, 2019; Published: March 10, 2020

\begin{abstract}
This work aims to highlight the impact of Community funds on the capacity to create financial value of Portuguese companies. We develop a theoretical framework with a reflection on various topics relevant to research, namely the importance of investments for companies, the concepts of financial performance and the logic of value creation, the metrics for value creation and the cost of capital. In addition, we have looked at several studies with similar research objectives to observe the methodologies used and the research results achieved. The study we developed looked at the 166 companies that benefited from EU funds in 2014 under the Sistema de Incentivos à Inovação, which is a part of the EU Incentives System for Research and Technological Development. To measure value creation capacity, we used EVA, since it is an indicator which allows you to easily measure the value created in each period and can be obtained directly from the financial statements of companies. The research results showed that the companies studied presented a greater capacity to create value, create employment and internationalize the activity in the financial year 2016 (although only job creation and internationalisation have shown statistically relevant differences). However, the statistical tests performed did not show any relationship among companies' best performance in the three indicators and the subsidies received, which means that, eventually, such positive developments have occurred due to other factors, such as the very favorable evolution of the Portuguese economy.
\end{abstract}

Keywords: Financial Performance, Value Creation, Investments, Subsidies, EU Funds

\section{Introduction}

Over the last few years business management has become quite complex, leading to constant risks in the business context resulting from economies' globalization, not only by the frequent change in the organizations' proprietary structure, but also due to technological innovation and competitiveness in the global market. The sum of all the factors referred to above, has substantially increased the level of risk in current or strategic management decisions taken within the scope of the organizations' activity. In this scenario, there has been a noteworthy concern about financial value creation, since it allows to verify companies' capability to remunerate investors, both owners and financial institutions, considering the total cost of invested capital.
Neves [1] found that there is currently an increasing concern about creating value, to the detriment of simple profits analysis. That is, it is increasingly consensual the idea that results are only beneficial to both prosperity and perpetuity of an organization, if they can reward the total invested capital, with value creation, if they exceed the cost of the investment made.

In parallel, over the past few decades, Portuguese companies have benefited from EU funds that are supposedly allocated with the aim of strengthening their competitiveness and their capacity to create value in a business context increasingly complex and more subject to international competition. Although it is a very relevant theme for the Portuguese economy, few studies have been developed on the impact of these funds on national companies. 
Thus, the aim of this research work is to study the impact of EU funds on Portuguese companies, by analyzing companies that have benefited from European incentives under the Innovation Incentive System, since it covers financing investments of global and strategic nature in productive areas. In this sense, the sample includes the 166 companies that had projects approved in 2014 and aims to verify the impact of these incentives on the capacity of value creation, as well as on job creation and internationalization level. To measure this impact, we took as reference the economic and financial data for the financial year 2016 and used several statistical techniques such as differences in means and multivariate linear regression.

In addition to the introduction, four parts make up this work, namely the theoretical framework, which develops the importance of the investment decision and the various studies analyzed on the impact of subsidies on the performance of companies, creation of value and cost of capital; the empirical study, which contains the most detailed description of the objectives and research methodology; analysis and discussion of results and the general conclusions of the work.

\section{Theoretical Framework}

\subsection{The Importance of Investment Decision}

From a microeconomic perspective, Martins, et al. [2] interpret the concept of investment as an application of funds generating financial surpluses, which aims to maximize the value of the company, in a given time horizon.

The reasons for investing can be diverse, stressing production increase to respond to bigger market demand, technological innovation with to achieve cost reduction or productivity gains, the use of synergies and feat of scale economies, through diminishing fixed costs per produced unit and increasing profitability [3].

Solnik [4] also understands investment as a considerable capital hold that generates a certain long-term profitability, albeit hypothetical and risky.

For Pettinger [5] investment is anything in relation to which a profitability is expected. Thus, people invest capital, time, energy and personal commitment and resources in ventures.

According to Araújo [6], investments are very important for a company's future, because it provides the necessary resources to obtain competitive advantages when facing competition, allowing to create conditions for resilience, for challenges and changes. Investments allow activity expansion and, eventually, market share growth. On the contrary, if poorly prepared, investments may hurry companies' decline. Thus, according to Marques [7], in order to make an investment, there needs to be an expectation of recovery and, in the long term, results that justify the cost, through a remuneration that overcomes it.

In this regard, Neves [1] states that investment decisions are based on the company's mission and strategy, which should focus on creating value for owners and therefore should consider profitability and potential associated risks.

According to Soares, et al. [8] investment decisions should take place after a circumstantial analysis of industry structure and internal resources. Strategic investment options should be based on the strengths and weaknesses, threats and opportunities facing the company. Such an analysis should also assess whether the investments to be made will ensure economic and financial benefits over the years, able to cover their operating cost and, at the same time, create value for investors.

For Teixeira and Amaro [3], business strategic investment decisions that companies have to make aim its financial sustainability over time. They condition both production capacity as well as creation of competitive advantages, typically involving large amounts of capital from the owners or negotiation of medium-term financing sources that will condition the company's treasury for a long time.

Thus, investment decision should be based on a careful analysis of economic and financial viability of projects to be carried out, because bad decisions might condition the competitive capacity of companies, through the development of skills not valued by the market or financial bottleneck, through treasury deficits [3].

\subsection{Investment Grants}

Investment grants represent an important source of financing for the development of companies. They assure (total or partial) coverage for assets acquisitions considered to be strategic for competitive advantages creation and for business sustainability. In this way, they allow to diversify financing sources and to reduce the cost of capital, reducing the need to resort to capital entries from the owners or to negotiation with financial institutions.

Generically, investment grants may have two natures: nonreimbursable and reimbursable.

Non-reimbursable grants are characterized by financing corporate investments without capital repayment or remuneration.

Reimbursable grants refer to amounts of capital allocated for the financing of investments, which will subsequently have to be paid to the entities that granted them. Usually, they also have no associated remuneration and the repayment of outstanding capital only begins after two-year or threeyear of grace period, giving companies the opportunity to reach its full rhythm, to generate financial surpluses capable of securing payments. It should be noted that sometimes such reimbursable grants are allocated with the possibility of becoming, in whole or in part, in non-refundable grants. This premise is usually associated with achieving economic targets by beneficiary companies contributing to the country's economic development. In Portugal, this hypothesis exists in the Innovation Incentive System, where companies may eventually turn $75 \%$ of the amount of reimbursable subsidies into non-repayable.

Despite the importance of investment grants in the development and modernization of companies, there are few empirical studies that explore their effect on performance. 
Beason and Weinstein [9] studied the support instruments to industrial policy in Japan and did not see any evidence of increased productivity in companies that had benefited from these policy measures.

Lee [10] noted the impacts of the Korean government's industrial policy on productivity growth in the manufacturing industry and has highlighted the fact that tax incentives and subsidized credit were not related to production factors' efficiency.

Bergström [11] looked at the impact of subsidies on business productivity in Sweden. He assumed that there was a positive correlation between grants and productivity, because it would be associated with companies' technological modernization and scale economies. The correlation between grants and the increase in companies' value has been confirmed. Furthermore, the author found that companies' productivity increased in the first year after the grant, but that this was not observed in the following years, calling into question the efficiency of its use.

In a research work on two sets of companies, one from Northern Ireland and the other from the Republic of Ireland, Roper and Hewitt-Dundas [12] also showed that government aid granted to sample companies had not had an impact on their turnover growth, nor on profitability. These government support had only had a significant impact on job creation. Despite the social importance of job creation, researchers warned about increased fixed costs on employees, which could have potentially pernicious implications, in the medium and long term, on the companies' competitive position, by the negative effect that over-workers would have on productivity and jobs to be created.

Tzelepis and Skuras [13] in a study aimed at investigating the impact of subsidies on corporate financial performance, concluded that they had only a positive effect on their growth.

On the other hand, a mid-term evaluation study of the COMPETE- Operational Program Competitiveness Factors, prepared by Augusto Mateus \& Associated and PricewaterhouseCoopers (PwC) in 2013 [14] advocates the existence of incentive systems for businesses, as, although much of the supported investment is headed for the reequipment, will often tend to be accompanied by resizing and/or internal reorganization processes, with a potential impact on business profitability.

In another study by Cerqua and Pellegrini [15] on Italian companies, it was concluded that the impact of grants on employment, investment and turnover was positive and statistically significant. However, the effect on productivity was virtually nil. These authors suggested that companies, in order to obtain higher amounts of funding, could be induced to exceed the ideal number of workers. Such behaviour would tend to affect the efficiency levels of enterprises in the long term.

And Carvalho [16] found that subsidies under the Innovation Incentive System had not had a significant impact on the gross margin of the companies that had received them.

The research results on the impact of grants on corporate financial performance have therefore been inconclusive, and there is different evidence on their importance to the competitiveness of beneficiary companies.

\subsection{Financial Performance Assessment}

According to Teixeira and Amaro [3] traditionally, the concept of financial performance is related to accounting information provided by Financial Statements, as is the case of the Balance Sheet, Profit and Loss Account and Cash Flow Statement. In addition, the same authors report that financial performance summarizes management decisions' impact on the capacity to generate results, profitability vis-vis investments made, the company's cash situation and its financial sustainability over time.

Thus, the assessment of financial performance of for-profit entities is one of the most important perspectives, as it summarizes the impact of all management decisions on value creation capacity.

However, according to Neves [1] there is currently an increasing concern about creating value over the mere profits analysis, that is, it is increasingly consensual that results are only beneficial to an organization prosperity and perpetuity if they can reward the total invested capital, having value creation if they exceed the cost of the investment made.

Nowadays, there is a diverse set of perspectives for financial performance assessment, but there is no unanimity as to the indicators to be used. Thus, the different indicators of financial performance assessment, with a view to creating value, can be organized according to the following perspectives [3]:

1. Accounting results;

2. Profitability;

3. Cash flows.

\subsection{The Assessment of Financial Performance Through the Logic of Value Creation}

The evaluation of value creation can be done by dividing indicators into three distinct groups, being these indicators of results, of profitability and of cash flows [17].

Firstly, we would like to clarify that any of the indicators mentioned, which measures value creation, can be calculated in two perspectives: that of the owners and that of the company [18]. This work focuses on the capacity of the company's activity to create value, not considering the type of investor. Thus, what is intended to study is the overall capacity of the business to release results, that are able to exceed the remuneration desired by the owners and financial partners, on the activity investments, and not only the expectations of the first.

Starting with the results indicators, consider the results created in the activity in relation to the cost associated with the necessary investment. These indicators are Economic Value Added (EVA) and Cash Value Added (CVA), which try to measure the ability of companies to generate supranormal profits.

EVA is a measure of assessment of the company's financial 
performance, which seeks to measure the value created by management. This value is created whenever the business can generate a result greater than the cost of capital. It is determined by the difference between net operating income (NOI) and the amount of results required by the owners and creditors. Thus, it corresponds to the business results surplus in relation to the funders required result [18].

$$
\mathrm{EVA}=\mathrm{NOI}-\text { Investment } \times \text { Capital cost }
$$

In this way, it should be concluded that EVA is the value created in view of the opportunity cost of the capital invested in an organization, all financial costs (debt and equity) being included in its calculation, clearly differentiating itself from the traditional measures of assessment of an organization's financial performance such as ROI-Return On Investment [19].

CVA is an indicator that allows you to evaluate the financial performance of an organization, combining the advantages of measures based on supranormal profits with the concept of cash flows [20]. According to Neves [18], calculation formula of the CVA is identical to that of the EVA, the difference lies in the replacement of Net Operating Income (NOI) by Liquid Operating Means (LOM-net operating tax results, plus non-payable costs). It should be noted that this indicator includes non-payable costs as period results, as it represent fiscally accepted costs, but that do not require any monetary exit from the company, which means that they are income that contribute to the creation of selffinancing that should be considered in the ability to release surpluses from the business. Furthermore, in doing so, results are not conditional on the different accounting policies adopted by companies, regarding depreciation and amortization, impairments and provisions [3].

$$
\text { CVA }=\text { LOM-Investment } \times \text { Capital cost }
$$

or

\section{$\mathrm{CVA}=\mathrm{EVA}+$ Non-payable costs-Investment $\times$ Capital cost}

Being similar indicators in logic and calculation formula, Young and O'Byrne [20] draw attention to the fact that EVA has the advantage of highlighting the ability of the business to cover all the costs arising from the activity.

With regard to value creation indicators based on profitability, we highlight Supranormal Profitability (SP) and Cash Flow Return On Investment (CFROI).

SP is based on the comparison of generated profitability with the cost of the capital of the investment made, starting in practice from the same principles as EVA [21]. The profitability generated is represented by ROI, as it observes the relationship between the results created by the activity with the necessary investment. As for the cost of capital, its calculation will be discussed later.

$$
\mathrm{SP}=(\text { ROI-Capital cost }) \times \text { Investment }
$$

Thus, through formula analysis, it can be concluded that there is value creation if the profitability created exceeds the cost of capital. This margin, multiplied by the amount of investment, shows the capacity to create value in monetary units and must have an identical result to EVA [22].

As for CFROI, it emerged as an alternative to ROI and was created by CSFB-Holt Value Associates [1]. However, it is the most difficult indicator to operationalize. Its objective is to determine an internal rate of profitability (IRR) that considers the current value of the investment (non-current assets and existing business working capital needs), its useful life and the yearly net operational means, which are considered as a reference for the following financial years. In addition to these procedures, values should be calculated at current prices. In the last year, the residual value of existing assets is considered to determine the IRR of the analyzed time period [18]. In practice calculation formula is as follows:

$$
\begin{gathered}
\mathrm{CFROI}=-\mathrm{EACP}+\mathrm{NOMCP} /(1+\mathrm{IRR})+\ldots+\mathrm{NOMCP} /(1 \\
+\mathrm{IRR})^{\mathrm{n}}+\mathrm{RV} /(1+\mathrm{IRR})^{\mathrm{n}}
\end{gathered}
$$

Legend: EACP-Economic assets at current prices; NOMCP-Net operating free means at current prices; RVResidual value

Thus, due to the way it is calculated, several criticisms are pointed out to this indicator [1]:

1. The way inflation has an impact on each type of asset is very subjective, and it is very difficult to operationalize its effect for determining created value;

2. The fact that the net tax release means are always equal over the years is a utopia, which does not represent the real capacity of companies to create surpluses during the analyzed period;

3. Investment in working capital is not considered in the predictable years, because it is assumed that it also does not change its value regarding the year considered as investment, which is also not correct;

4. Thus, an IRR is being determined regarding potential results and not on cash flows, which does not meet the one advocated by financial theory.

In practice, CFROI is calculated through similar procedures as to investment projects evaluation, having as main difference the fact that it does not work with cash flows but rather, with free means. In this way, it intends to verify the profitability that investments could provide, considering the current activity capacity, to generate expected lifetime financial surpluses of existing assets.

As far as cash flows are concerned, they are a powerful financial planning and control instrument, since they allow investors to observe the real capacity of the business to create cash flows and are not influenced by accounting record criteria, such as depreciation and depreciation and impairments, which influence the level of generated surpluses, when they are measured through results or liberated means [23]. Thus, they allow a clear view of the cash situation of companies, representing the actual monetary flows of an investment or organization and are calculated by the difference between all entries and withdrawals of funds [19]. 
Michael Jensen [24] in research work called "Agency Cost Of Free CashFlow, Corporate Finance, and Takeovers," considered cash flows fundamental to financial performance assessment and introduced the concept of Free Cash Flow, highlighting the Free Cash Flow to Firm (FCFF) or Operational Cash Flow in business valuation.

Operating Cash Flow (OCF) illustrates the surplus generated by an organization's business after covering investments in non-current assets and working capital needs, necessary for its operation, without considering the form of funding selected [18]. Therefore, the OFC is determined as follows:

$$
\mathrm{OCF}=\mathrm{OI} \times(1-\mathrm{t})+\mathrm{D}+\mathrm{P}-\Delta \mathrm{WCN}-\mathrm{I}
$$

Legend: OI-Operational Income; t-Tax rate; DDepreciation and amortization; P-Provisions and Impairment; $\triangle \mathrm{WCN}-$ Working Capital Needs variation; I-Fixed capital investment (Exploration))

So, the OCF highlight the funds flowing from the operational activity which are available to cope with the compensation required by different investors, owners and financial institutions.

Finally, in order to measure the capacity to create value, it is essential to consider the cost of invested capital, i.e. the remuneration required by investors. Thus, Neves [1] recommends the use of economic value created (EVC) and internal rate of effective return (IRRE) indicators, which are indicators based on historical cash flows. Its calculation is based on the capitalization of the various cash flows to the end of the last year under analysis, verifying the profitability generated throughout the implementation of the investments that were previously designed.

Thus, EVC and IRRE allow bridging the gap between the evaluation of estimated investments and the control of their implementation, by comparing the estimated values of NPV and IRR (net present value and internal return rate) with created cash flows, considering required compensation. EVC and IRRE can be calculated as follows:

$$
\begin{aligned}
& \mathrm{EVC}=\mathrm{OCF} 1 \times(1+\text { cost of capital })^{(\mathrm{n}-1)}+\mathrm{OCF} 2 \times(1+\text { cost } \\
& \text { of capital })^{(\mathrm{n}-2)}+\ldots .+ \text { OCFn } \\
& 0=\mathrm{OCF} 1 \times(1+\mathrm{IRRE})^{(\mathrm{n}-1)}+\mathrm{OCF} 2 \times(1+\mathrm{IRRE})^{(\mathrm{n}-2)}+\ldots .+ \\
& \text { OCFn }
\end{aligned}
$$

In conclusion, we can verify that all indicators of value creation, although starting from different bases (results, profitability and cash flows), always aim to verify the ability of the business to generate a remuneration higher than the cost of capital required by different investors, owners and financial institutions.

In this sense, the concept of the cost of capital will be addressed next.

\subsection{The Concept of Cost of Capital}

The concept of "cost of capital" is usually associated with the return that a particular investment should provide, defined as the remuneration rate required by investors, taking into account its business risk. In particular, at company level, the concept of "cost of capital" relates to investor decisions on the assets in which to invest and how to finance them, bearing in mind maximizing the value of the organization [21].

Business activity can be essentially supported through debt financing and equity, both having associated a specific cost, which varies depending on the risk incurred by the different investors. Usually owners demand higher reward. This is because they have a greater concern with business management, and because they risk, in case of bankruptcy, to have access to existing assets only after the fulfilment of third parties' obligations. Based on this idea of different costs for the various sources of financing, the concept of weighted average cost of capital arose. It is better known for its English designation, WACC - weight average cost of capital. Its calculation formula is as follows [21]:

$$
\mathrm{WACC}=(\mathrm{E} / \mathrm{A}) \times \mathrm{Ke}+(\mathrm{L} / \mathrm{A}) \times \mathrm{Kd} \times(1-\mathrm{t})
$$

Legend: E-» Equity; A-» Liquid Asset; Ke-» Cost of Equity; P-» Liabilities; $\mathrm{Kd}-»$ Cost of debt financing; $\mathrm{t}-\gg$ Income tax effective rate.

Having this formula as a reference, the optimal capital structure (or optimal indebtedness level) is the one that minimizes WACC and consequently maximizes company value.

WACC comprises the sum of the costs of equity and liabilities, duly biased by its weight in net assets financing. This information may help managers considering cheaper financing sources, lowering the cost of capital. By decreasing the value of the WACC, management may also contribute to value creation because reducing the cost of investment increases the value of financial surpluses [17].

The cost of financing sources is often determined by contracted interest rates applied by financial institutions, or through the relationship between periodic financial expenses and paid liabilities at the end of the previous year [18].

With regard to the cost of equity, in the case of listed companies, it is represented by the expected profitability, determined through the Capital Asset Price Model (CAPM), which measures the remuneration to be required by owners on the basis of market profitability and the risk associated with securities. In other cases, it may be calculated by reference to the average profitability of own capital in the activity sector, or the addition of a risk premium to the cost of bank financing in the company [18]. In this regard, Damodaran [25] and specialized organizations, such as COFACE, suggest the use of risk premiums as a reference, according to the risk of the countries where they operate.

\section{Empirical Study}

\subsection{European Union Funds in Portugal}

Currently, Portugal is benefiting from the Portugal 2020 PT2020 Program (2014-2020), the community framework that is taking place. This program comes through a Partnership Agreement established between Portugal and the 
European Commission, through which Portugal is receiving a total of $€ 25$ billion by 2020 , with the aim of stimulating growth and job creation in the country, being properly aligned with the principles of the Europe 2020 Strategy, which is based on Smart, Sustainable and Inclusive Growth (www.portugal2020.pt, 2018).

Portugal 2020 (PT2020) brings together the five European Structural and Investment Funds (ESI Funds) - the three Cohesion Policy Funds (European Social Fund, European Regional Development Fund and Cohesion Fund), the European Agricultural Development Fund and the European Fund for Maritime Affairs and Fisheries (www.portugal2020.pt, 2018). The ESI Funds are the European Union (EU) regional policy financial instruments that aim to reduce the asymmetries amongst the various countries and regions, thus contributing to achieving the goal of economic, social and territorial cohesion in the European integration process (www.portugal2020.pt, 2018).

In order to operationalize the implementation of European funds, with a particular focus on business initiative, Portaria No. 57-A/2015 of 27 February, article $3^{\text {rd }}$ approved the Specific Regulation on the Field of Competitiveness and Internationalization (RECI), through which defines that the system of companies incentives provided for in the RECI covers the following investment typologies:

1. Business innovation and entrepreneurship;

2. Qualification and internationalization;

3. Research and technological development.

The objective of the System of Incentive to Business Innovation and Entrepreneurship, according to articles $19^{\text {th }}$ and $20^{\text {th }}$ of RECI, is to promote innovation in Portuguese businesses. This Incentive System seeks the way for the production of new goods, services and processes that support their progression in the value chain and the strengthening of its orientation to international markets. It also aims to introduce technological improvements, creating production units, stimulating qualified entrepreneurship, and structuring investment in new areas with potential growth.

The Qualification and Internationalization Incentive System aims, according to Article $40^{\text {th }}$ and $41^{\text {th }}$ of the RECI, promoting the competitiveness of small and medium-sized enterprises (SMEs) by increasing productivity, flexibility and responsiveness and active presence of SMEs in the global market. It supports investment in dynamic competitiveness factors, including industrial property, brand creation, the creation or strengthening of laboratory capabilities, organization and management, the implementation of information and communication technologies, quality, environment, innovation, digital economy, among other.

The Incentive System for Research and Technological Development defined in Articles $60^{\text {th }}$ and $61^{\text {th }}$ of the RECI consists of research and technological development projects (R\&DT) and technological demonstration, led by SMEs, and can be developed in cooperation with entities of the National Technical and Scientific System. These projects shall involve industrial research and/or experimental development activities, leading to the creation of new products, processes or systems or the introduction of significant improvements in existing ones.

Managing Authorities of their Operational Programs or other competent entities review all the applications, serializing it and punctuating it according to each contest criteria. Applications whose decision is favorable have access to two types of EU support: non-reimbursable grants and reimbursable allowances, usually with several years of grace period and the possibility of being partly transformed into non-reimbursable, if the applied foreseen economic targets are met.

\subsection{Research Objectives and Methodology}

The general objective of this research work is to verify whether allocated EU funds have had a positive impact on Portuguese companies' financial value creation.

Taking into account the results of analyzed studies on the subject and the outlined strategy under Portugal 2020, EU funds are expected to contribute to greater profitability creation of Portuguese companies, as well as employment and greater internationalization capacity. This is because they supposedly allow greater access to capital that eases strategic investments financing, which are fundamental for creating sustainable competitive advantages.

To achieve the overall objective set, we studied companies that obtained EU funds under the Innovation Incentives System (SI Innovation) in 2014. We chose to analyze companies that benefit from this incentive system, because SI Innovation finances crosscutting productive projects in different organizational areas. The other incentive systems focus on specific areas of enterprises, not having such a comprehensive impact on their activity.

For the years analyzed, the study focused on the economic and financial values of the 2014 and 2016 financial years. As a rule, companies have 24 months to make the investment and so we looked at those that benefited from funds in 2014, hoping that the financial year 2016 (the first after the completion of the planned investments), could show a positive impact on activity value creation of the companies targeted by the study. Thus, the sample consists of 166 companies.

The sources of information used were economic and financial data from the SABI database - Iberian Balance Sheet Analysis System, data on companies that received incentives in 2014 and their amounts from the Portugal 2020 website.

Thus, based on incentive companies in 2014 under SI Innovation, and the overall objective defined, we formed four hypotheses of research to support the development of the study:

H1: The 2016 EVA is significantly higher than the 2014 EVA.

H2: The number of people employed in 2016 is significantly higher than in 2014 .

H3: The level of internationalization in 2016 is significantly higher than in 2014.

H4: The allocation of EU funds presents a positive relationship with financial value creation, job creation and 
internationalization capacity.

With regard to the financial concepts considered throughout this work to determine value creation capacity of studied companies, and due to their importance for research reliability, we will detail the calculation of used economic and financial items.

The indicator used to measure value creation capacity was EVA. This choice considered that this indicator allows you to easily assess value creation, being calculated through the data contained in the financial statements.

For the determination of EVA, we used Net Results Without Financial Leverage as business results (NRWFL), in order to include all economic flows except from those associated with the financial decision. We obtained the NRWFL by applying the following formula:

$$
\mathrm{NRWFL}=(\mathrm{OR}+\text { Financial income }) \times(1-\mathrm{t})
$$

Legend: NRWFL - net results without financial leverage; OR-operational results; $t$-effective rate tax

To determine the investment, we used the value of the total net asset to include all investments made in the activity.

Regarding the cost of capital (equity and debt capital), we determine it through WACC, calculating the following variables: effective tax rate $(\mathrm{t})$, cost of debt capital $(\mathrm{Kd})$, cost of equity (Ke), invested capital, liabilities and equity.

Effective tax rate was calculated by the correlation between the amount of corporate income tax - IRC and results before taxes - RAI [1].

Cost of debt capital was obtained through the correlation between financial expenses recorded in the income statement and the value of liabilities in each economic year [1].

Cost of equity was calculated by adding a risk premium to cost of debt capital, determined according to the preceding paragraph. The risk premium was determined according to the amounts made available on Aswath Damodaran's [25] website, relatively to the risk of countries. To Portugal, the risk premium considered is $4.86 \%$.

For the amounts of invested capital (in this case represented by total net assets), equity and liabilities, we used those of companies' annual balance sheet.

As for the statistical techniques used, and considering defined hypotheses, we highlight some. First, we used descriptive statistics to better characterize the selected sample in relation to its economic and financial data.

In hypothesis 1 , to find out the significant differences in EVA values from 2016 compared to 2014, we used tests of differences in means for paired (related) samples. These tests focused on the indicator used to measure value creation (EVA), as well as on the different items that make up it, particularly on NRWFL, investment and WACC. We therefore expect to get a more detailed view of the differences in the creation of financial value of the companies studied, between 2016 and 2014.

Also, in hypothesis 1 , we used multivariate regression models to study the economic items influencing the formation of NRWFL and the value of investment, in order to explain in more detail, the formation of EVA of the various companies analyzed.

The model can be generically displayed by the following formula:

$$
\mathrm{Y}=\beta 0+\beta 1 \mathrm{X} 1+\ldots+\beta \mathrm{kXk}+\mathrm{E}
$$

Legend: $\mathrm{Y}=$ dependent variable $\rightarrow$ created value - EVA; $\beta$ $=$ Constant; $\mathrm{X} 1, \ldots, \mathrm{XK}=$ independent variables; $\mathrm{E}=$ mediation error.

The independent variables used for the study include $\mathrm{K}$ factors $(\mathrm{K}=1, \ldots, 11)$ and refer to economic and financial data that may condition value creation.

In the model that aims to study the relationship between EVA and economic items, independent variables are constituted by variations of operating income, financial income, cost of sold goods and consumed materials, personnel costs, amortizations and depreciation, income taxes and other operational expenditures, including external supplies and services, impairment, among others. The model that aims to study the relationship between EVA and financial items, the independent variables are represented by variations in non-current assets, Inventories, third-party debts, other current assets, Equity, Provisions, non-current liabilities and current liabilities.

Finally, in hypothesis 1 , there were still possible differences in the level of value creation in 2016, in the sectors of activity and regions, where the companies studied are inserted.

As regards hypotheses 2 and 3, tests of differences in averages were carried out to enable possible job increases and the level of internationalization of the companies studied in 2016, compared to the 2014 economic year data.

With regard to hypothesis 4 that aims to measure the relationship between the incentives allocated and the creation of financial value, job creation and the level of internationalization, we have carried out simple linear regression models, to evidence the type of relationship (significant or not) between the different variables studied (EVA, number of employees, level of internationalizationweight of international turnover compared to total turnover and amount of incentives received by companies).

\subsection{Analysis and Discussion of Research Results}

After the analysis of the sample consisting of 166 companies, we observed that several of the projects supported by SI Innovation have not been properly implemented over the years under study. In addition, we have verified the existence of 2 outliers in terms of economic and financial data. Thus, the final sample integrated only 144 companies.

Under hypothesis 1 we want to verify whether the 2016 EVA exceeded 2014, within companies that obtained Community incentives under SI Innovation.

In this sense, we perform a parametric test (student $\mathrm{T}$ ) of differences in means of samples related to. In 2016, the 145 companies studied presented an EVA with an average value of EUR 389,000, while in 2014 the same indicator had the value of EUR 225,000. Although, on average, the $2016 \mathrm{EVA}$ has a value much higher than in 2014, the difference found is not statistically significant (the significance degree is 0.367 , 
well above the 0.05 normally considered as a reference). However, the result of the corresponding nonparametric test (Wilcoxon test) presented a significance level of 0.047 , therefore being relevant to an $\alpha<0.05$.

Thus, in statistical terms, although from 2014 to 2016 there is an increase of about $73 \%$ of the EVA of companies that have obtained Community incentives under IS Innovation, it is certainly not possible to show that such developments are significant.
To observe in greater detail EVA evolution from 2014 to 2016, we also perform tests of differences in averages of the remaining variables that condition its calculation: NRWFL, WACC and investment level.

The following table presents the mean values in 2014 and 2016 of the variables studied and the significance level of the tests of differences of means performed (parametric and nonparametric).

Table 1. Statistics from RLSAF, WACC and investment level.

\begin{tabular}{|c|c|c|c|c|}
\hline Variables & Average 2014 (thousand euros) & Average 2016 (thousand euros) & Parametric Test $(\alpha)$ & Nonparametric test $(\alpha)$ \\
\hline NRWFL & 992,115 & 920,469 & 0,816 & 0,059 \\
\hline WACC & $4,49 \%$ & $2,65 \%$ & 0,226 & 0,018 \\
\hline Investment & $13.916,51$ & $16.559,57$ & 0,00 & 0,00 \\
\hline
\end{tabular}

As we can see, in parametric tests the level of significance is only relevant in the differences in investment values of 2016 and 2014, which will be directly associated with the execution of projects supported under SI Innovation. However, in nonparametric tests there are significant differences in all variables studied (differences in WACC and investment are relevant to an $\alpha<0.05$ and those of NRWFL for an $\alpha<0.1$ ).

Previously we verified that EVA achieved a positive evolution from 2014 to 2016 . By analyzing the variables that constitute EVA, we observed a negative evolution in the level of results and investment, but on the other hand we saw an average decrease in the cost of capital used from $4.5 \%$ to $2.7 \%$. This reduction in the cost of funding sources has contributed to mitigating the negative impact of NRWFL developments and investment and to an absolute increase in EVA indicator, from 2014 to 2016.

Then, to better characterize the origin of the value creation of the companies studied between 2014 and 2016, e performed two models of multiple linear regression with the variation of EVA as a dependent variable, using as independent variables the variations in economic items (included in the income statement) and financial items (included in the balance sheet).

The regression models elaborated were subject to the tests recommended by Pinto and Curto [26], which intended to confirm its validity. Therefore, we consider relevant the following comments:

1. Linearity of the relationship between the variables of the model: no linear relationship was found between the residues and the estimated values of the dependent variables;

2. Homogeneity of variance: heterocedasticity was detected in both models. As such, the White test was performed to verify the significance of the variables with the robust standard deviations, and in most cases the same types of results were maintained (both at the level of relevance and the sign of the coefficients);

3. Normality of errors: none of the models held a normal distribution. However, given the size of the sample studied, more than 30 units, we can consider the results robust [27];

4. Multicollinearity: the observation of Pearson's correlation coefficients, as well as the values of the VIF indicator, allowed us to verify that the cost of sold goods and consumed materials (in economic variables) and the value of non-current assets (in financial variables), presented strong relationships with remaining studied variables. Thus, in the model that studied the economic variables, gross margin was used instead of operating income and the costs of sold goods and consumed materials; in the model that studied the financial variables, we chose to withdraw the noncurrent asset, since it was already an expected basis that presented a strong relationship with EVA. Making these adjustments, the final worked models did not present any problem of multicollinearity.

At the level of economic variables, we found that the headings with the greatest impact on EVA were gross margin, staff costs and other operating expenses (where external supplies and services are included). Taxes and yearly amortizations and depreciation also revealed relevant significance levels, also conditioning EVA value.

Table 2. Statistics of the regression model of economic variables.

\begin{tabular}{ll}
\hline Dependent variable & Results \\
\hline & 1. $\mathrm{R}^{2}$ Adjusted $=0,573 \rightarrow \mathrm{p}$-value $=0,000^{*}$ \\
& 2. Gross margin variation $\rightarrow$ Coefficient $=1,048 ; \mathrm{p}$-value $=0,000^{*}$ \\
& 3. Personnel costs variation $\rightarrow$ Coefficient $=-1,307 ; \mathrm{p}$-value $=0,000^{*}$ \\
4. Amortizations and depreciation variation $\rightarrow$ Coefficient $=-0,956 ; \mathrm{p}$-value $=0,000^{*}$ & 5. Financial income variation $\rightarrow$ Coefficient $=2,710 ; \mathrm{p}$-value $=0,146$ \\
EVA Variation 2016-2014 & 6inancial expenses variation $\rightarrow$ Coefficient $=-4,863 ; \mathrm{p}$. value $=0,172$ \\
& 7. Taxes variation $\rightarrow$ Coefficient $=-0,874 ; \mathrm{p}$-value $=0,037 * *$ \\
& 8. Other operating expensesvariation $\rightarrow$ Coefficient $=-1,135 ; \mathrm{p}$-value $=0,000^{*}$ \\
\hline
\end{tabular}

$*$ Significant for $\alpha<0,01 ; * *$ Significant for $\alpha<0,05$. 
In financial variables, the model showed that, in addition to the value of non-current assets, none of the items studied presented a statistically significant relationship with the variation occurred in EVA from 2014 to 2016.

Table 3. Statistics of the regression model of financial variables.

\begin{tabular}{ll}
\hline Dependent variable & Results \\
\hline & 1. $\mathrm{R}^{2}$ Adjusted $=0,161 \rightarrow \mathrm{p}$-value $=0,000 *$ \\
& 2. Inventories variation $\rightarrow$ Coefficient $=-0,005 ; \mathrm{p}$-value $=0,987$ \\
& 3. Third-party debts variation $\rightarrow$ Coefficient $=0,188 ; \mathrm{p}$-value $=0,247$ \\
& 4. Other current assets variation $\rightarrow$ Coefficient $=0,345 ; \mathrm{p}$-value $=0,113$ \\
& 5. Equity variation $\rightarrow$ Coefficient $=0,012 ; \mathrm{p}$-value $=0,947$ \\
Variation EVA $2016-2014$ & 6. Non-current liabilities variation $\rightarrow$ Coefficient $=-0,247 ; \mathrm{p}$. value $=0,294$ \\
7. Provisions variation $\rightarrow$ Coefficient $=-0,485 ; p$-value $=0,899$ & 8. Current liabilities variation $\rightarrow$ Coefficient $=-0,094 ; p$-value $=0,523$ \\
\hline
\end{tabular}

Thus, it is observed that, in addition to the value of the investment (non-current assets), which had a very strong relationship with EVA, and therefore was removed from the model, are fundamentally economic items (gross margin, personnel costs and other operating costs), which condition NRWFL creation and which have a greater impact on EVA developments.

Finally, also under hypothesis 1 , to better characterize the creation of financial value resulting from the allocation of incentives under SI Innovation, we studied eventual differences in EVA created in 2016 in the different regions and sectors of analyzed companies.

Although there are differences in mean EVA values by region and by sector of activity, do not have a statistically relevant level of significance. In the regions, the ANOVA test performed showed a p-value of 0.729 ; in the activity sectors, the same test presented a p-value of 0.972 .

The following tables present the mean values of 2016 EVA found in each region and in each sector of activity.

Table 4. Average EVA values in 2016 by region.

\begin{tabular}{lll}
\hline Region & Number of companies & $\begin{array}{l}\text { EVA value (thousand } \\
\text { euros) }\end{array}$ \\
\hline Alentejo & 4 & $-186,04$ \\
Algarve & 1 & 285,89 \\
Center & 52 & 538,97 \\
Lisbon & 2 & $-176,12$ \\
Multi - Regions & 2 & $-1.416,12$ \\
North & 84 & 381,41 \\
\hline
\end{tabular}

Analyzing the values, one can verify that the regions with higher EVA were the Center and the North of Portugal, which also present by far the largest number of applications.

Table 5. Average EVA values in 2016 per sector of activity.

\begin{tabular}{lll}
\hline Activity Sector & $\begin{array}{l}\text { Number of } \\
\text { companies }\end{array}$ & $\begin{array}{l}\text { EVA Value } \\
\text { (thousand } \\
\text { euros) }\end{array}$ \\
\hline Activities from Primary sector industry & 52 & 365,71 \\
Activities from Manufacturing (CAE 2) & 65 & 467,19 \\
Activities from Manufacturing (CAE 3)) & 13 & 148,07 \\
Activities from Hotel business & 12 & 438,73 \\
Activities from Services & 3 & $-50,43$ \\
\hline
\end{tabular}

As for activity sectors, the activities of CAE 2 (Manufacturing) and Hotel business have the highest EVA values in 2016.
About research hypothesis 2 and 3, which intend to verify the increase in employment and internationalization level of companies that received incentives under SI Innovation in 2014, differences in averages tests were also carried out of between the values of 2014 and 2016.

In both cases, it was found that the differences that occurred between the years analyzed are statistically relevant, presenting p-values of 0.000 , in the case of an increase in the number of employees, and 0.043 , in increasing the level of internationalization. It is therefore noted that companies that benefited from incentives allocated under SI Innovation in 2014 created greater jobs and improved their capacity for penetration in international markets.

The following table highlights the average values of the number of employees and the level of internationalization in 2014 and 2016.

Table 6. Average values of the number of employees and the level of internationalization.

\begin{tabular}{lll}
\hline Indicators & $\mathbf{2 0 1 4}$ & $\mathbf{2 0 1 6}$ \\
\hline Number of employees & 120 & 135 \\
Level of internationalization & $47,44 \%$ & $50,13 \%$ \\
\hline
\end{tabular}

Finally, to validate the hypothesis of investigation number 4, simple linear regression models were performed between the value of received grants and the variation that occurred from 2014 to 2016 in EVA, number of employees and internationalization level.

According to Pearson's correlation coefficients presented in the table below, the connection between the value of the subsidies received and the variables under study is quite weak.

Table 7. Correlation coefficients between grants received and EVA, number of employees and internationalization level.

\begin{tabular}{ll}
\hline Variables & Coefficient \\
\hline EVA & 0,067 \\
Number of employees & 0,026 \\
Level of internationalization & 0,085 \\
\hline
\end{tabular}

On a scale ranging from $-100 \%$ (where variables have a perfect and inverse relationship) and $100 \%$ (where variables have a perfect relationship and in the same sense), grants received have a relationship with EVA variations, number of employees and internationalization level, in the order of $6.7 \%, 2.6 \%$ and $8.5 \%$, respectively. 
In conclusion, generically speaking, companies that have obtained incentives under SI Innovation improved their capacity to create value, to create jobs and to internationalize business from 2014 to 2016. However, it is not possible to statistically show that the improvement in the activity of these companies is directly related to the allocation of EU funds to carry out strategic investments in non-current assets. Thus, such evolution would be associated with other factors and, eventually, the very evolution of the Portuguese economy may have contributed to a better performance of the business of studied companies.

\section{Conclusion}

This work aimed to highlight the impact of Community EU funds on the capacity to create financial value in Portuguese companies.

To this end, we have developed a theoretical framework where we focus on several important topics for research, namely the importance of investments for companies, concepts of financial performance assessment, value creation logic, metrics to value creation and cost of capital. In addition, we have looked at several studies with similar research purposes to observe the methodologies used and the research results achieved by.

As regards the developed study, were analysed the 166 companies that benefited from EU funds in 2014 under the Innovation Incentive System. To measure the value creation capacity, we used the EVA indicator, since it allows to easily measure the value created in each period and can be obtained directly from the companies' financial statements.

The research results showed that the 144 companies studied presented a greater capacity to create value and employment and internationalize the activity in the financial year 2016 (although only job creation and internationalization presented statistically relevant differences). However, the statistical tests performed did not show any relationship between the best performance of companies in the three indicators and the subsidies received, and hypothesis 4 of investigation was not verified.

In addition, it was observed that the greatest conditioning (by positive) of value creation was the cost of capital, which decreased from 2014 to 2016, and that the economic items that had the greatest impact on EVA were, namely gross margin, personnel costs and other operating costs (including external supplies and services). Finally, there were no statistically relevant differences in EVA from the various regions and activity sectors of activity.

As regards the limitations of the investigation, it is noteworthy that there is little research work dealing with this issue, which makes it difficult to take a more complete view of the conclusions of the impact of EU funds on the companies' performance.

In the future research may be enriched by the analysis of more companies and more economic exercises, in order to have a more overall picture of the importance of EU funds in creating the financial value of Portuguese companies.

\section{References}

[1] Neves, J. (2011). Avaliação e Gestão da Performance Estratégica da Empresa. (2 ${ }^{\text {a }}$ Edição). Lisboa: Texto Editora.

[2] Martins, A., Cruz, I., Augusto, M., Silva, P., \& Gonçalves, P. (2009). Manual de Gestão Financeira Empresarial. Coimra: Coimbra Editora.

[3] Teixeira, N. \& Amaro, A. (2013). Avaliação do desempenho financeiro e da criação de valor. Revista Universo Contábil, 9 (4), 157-178.

[4] Solnik, B. (1995). Gestão Financeira: conceitos e modelos essenciais. Publicações Europa America.

[5] Pettinger, R. (2006). A decisão de investimento. Lisboa: Prefacio.

[6] Araújo, A. J. (1999). Manual de Análise de Projetos de Investimentos. Lisboa: Rei dos Livros.

[7] Marques, A. (2014). Conceção e Análise de Projetos de Investimento. $4^{\circ}$ Edição. Lisboa: Edições Sílabo.

[8] Soares, I., Moreira, J., Pinho, C., \& Couto, J. (2015). Decisões de Investimentos - Análise Financeira de projetos. Lisboa: Edições Sílabo.

[9] Beason, R \& Weinstein, D E, (1996). Growth, economies of scale, and targeting in Japan (1955-1990). The Review of Economics and Statistics, 78 (2), 286-295.

[10] Lee, J. W., (1996). Government interventions and productivity growth. Journal of Economic Growth, 1, 391-414.

[11] Bergström, F. (2000). Capital subsidies and the performance of firms. Small Business Economics, 14 (3).

[12] Roper, S. \& Nola H. (2001). 'Grant Assistance and Small Firm Development in Northern Ireland and the Republic of Ireland. Scottish Journal of Political Economy, 48, 99-117.

[13] Tzelepis, D. \& Skuras, D. (2006). Strategic performance measurement and the use of capital subsidies. International Journal of Productivity and Performance Management, 55 (7), 527-538.

[14] Augusto Mateus \& Associados \& Price Waterhouse Coopers, (2013). Estudo de avaliação intercalar do programa operacional fatores de competitividade (COMPETE). Relatório Final".

[15] Cerqua, A. \& Pellegrini, G. (2014). Do subsidies to private capital boost firms' growth? A multiple regression discontinuity design approach. Journal of Public Economics, $109,114-126$.

[16] Carvalho, A. (2014). Subsídios ao investimento na rentabilidade das empresas-O caso do SI Inovação. Faculdade de Economia da Universidade do Porto. Tese de Mestrado não publicada.

[17] Teixeira, N., Mata, C., Pardal, P., \& Teixeira, A. (2012). A aplicação da rendibilidade supranormal para a avaliação da criação de valor;. XXIII Jornadas Hispano Lusas de Gestão Cientifica. Malaga-Espanha.

[18] Neves, J. (2012). Análise e Relato Financeiro - Uma visão integrada de gestão. (5 $5^{a}$ Edição) Lisboa: Texto Editores. 
[19] Silva, E., \& Queirós, M. (2010). Gestão Financeira - Análise de Investimentos. Porto: Vida Economica.

[20] Young, S., \& O'Byrne, S. (2001). EVA ${ }^{\circledR}$ and Value Based Management. New York: MacGraw-Hill.

[21] Teixeira, N. (2008). A rendibilidade e a criação de valor. XIII Encontro AECA, Aveiro.

[22] Teixeira, N. (2013). A avaliação do risco e da criação de valor no contexto empresarial, in Empreendedorismo, Coesão Social e Dinâmicas Empresariais, Caderno da Sociedade e Trabalho ${ }^{\circ}$ 17, GEP/MSESS.

[23] Esperança, J., Matias, F. (2009). Finanças Empresariais (2a Edição). Alfragide: Texto Editora.
[24] Jensen, Michael C. (1986). Agency costs of free cash flow, corporate finance and takeovers. American Economic Review, 76 (2), 323-329.

[25] Damodaran, A. on-line. Available at 2019, em: http://pages.stern.nyu.edu/ adamodar/

[26] Pinto, J., \& Curto, J. (1999). Estatística para economia e gestão: instrumentos de apoio à tomada de decisão. Lisboa: Edições Sílabo.

[27] Moutinho, L. \& Hutcheson, G. (2008) Statistical Modelling for Management. London: SAGE. 